\title{
Short- and long-term ex post evaluation of community-based environmental initiatives in Chile
}

Cristian Mardones

\begin{abstract}
This study contributes to the limited literature on environmental impact assessments by undertaking an ex post evaluation of a programme to improve the environment through various community-based initiatives that promote education and citizen participation in Chile. In line with the selection criteria for the projects and the nature of the data available, the instrumental variables method is used to determine this programme's effect on perceived problems associated with multiple environmental issues. The results reveal that, in the short term, only the perception of odour pollution improves, while, in the long term, the impact on that issue increases twofold and the perception of air pollution and pollution caused by stray dogs both improve by a similar magnitude.
\end{abstract}

\section{Keywords}

Environment, environmental protection, community participation, programmes of action, project financing, evaluation, sustainable development, Chile

JEL classification

Q5, C26

\section{Author}

Cristian Mardones is an associate professor with the Department of Industrial Engineering of the University of Concepción (Chile). Email: crismardones@udec.cl. 


\section{Introduction}

Community-based environmental initiatives arise from a sense of community and individuals' motivation (Rees and Bamberg, 2014). According to Bamberg, Rees and Seebauer (2015), participation in these types of projects is underpinned by collective efficacy beliefs, identification with the group and individuals' participative efficacy beliefs. Waylen and others (2010) show that initiatives in which local institutions participate are more likely to be successful and, moreover, that an approach is needed that arises from within the community and is then extended to businesses and government (Walker and Devine-Wright, 2008). Blum (2008) notes that these initiatives are primarily linked to environmental education, conservation and engagement. Peters, Fudge and Sinclair (2010) describe green travel, recycling, energy efficiency and biodiversity initiatives. Pujadas and Castillo (2007) assert that the local population's participation is fundamental for the sustainable use of natural resources. Méndez-López and others (2014) evaluate local participation in the creation, design and implementation of the management plans of different conservation schemes in Mexico. The fact that community-based environmental initiatives encompass such a large number of issues shows that they have become increasingly important and commonly-used tools for mitigating environmental damage. However, the empirical literature has not settled the question of how to quantify the impact that can be attributed solely to this type of initiative (Feser, 2013).

To address this problem, impact evaluation methodologies, also known as ex post evaluations, can be used. These methodologies seek to identify the causal effect of a programme by comparing the result within the participating units with what the result would have been in the same units if they had not participated in the programme. However, this type of evaluation is difficult to carry out because it is impossible to observe both results at the same time. Fortunately, over the last three decades different statistical methods have been developed to estimate the counterfactual situation. According to Blundell and Costa Dias (2009), these methods can be classified on the basis of whether they use experimental, quasi-experimental and non-experimental designs.

This article seeks to contribute to this line of research by evaluating the causative impact of a Chilean environmental programme implemented through the Environmental Protection Fund (FPA), administered by the Ministry of the Environment. Each year this Fund awards grants to finance projects developed by social organizations to raise greater public awareness and appreciation of the environment by promoting environmental education and citizen participation.

Normally, the outcome variable to evaluate this type of programme should be the target population's perception of environmental quality before and after each of the implemented projects. However, for this study it would be very difficult to identify the impact of the projects, given the considerable variety of those financed by FPA. Therefore, in terms of the methodological approach, one or several outcome variables common to all the projects must be established to carry out a general assessment of the programme. In addition, the beneficiaries of this programme are not selected randomly by FPA from among the social organizations, rather organizations put themselves forward (self-selection) and are chosen on the basis of the quality of the project. Consequently, any viable strategy for the ex post evaluation of the FPA programme (quasi-experimental or non-experimental design) must take into account the fact that the selection criteria vary depending on the year of implementation, the number of applications, changes to the programme, available resources and the geographical area in question. All these factors make it difficult to create control groups for the financed projects. Moreover, since there are no records of the outcome variables (perception of problems related to various environmental issues) or of the characteristics of the applicant organizations that did not receive financing, once a project has been implemented neither a quasi-experimental evaluation strategy based on difference-in-difference techniques nor a nonexperimental evaluation using matching techniques or a regression discontinuity design can be applied. ${ }^{1}$

\footnotetext{
1 Furthermore, only a few projects receive financing each year (approximately 200) and the number has fallen quite close to the cut-off point, so this technique would not be useful either.
} 
Fortunately, the programme's participation criteria mean that an impact identification strategy, using instrumental variables, can be adopted. This technique corresponds to a non-experimental design that tries to isolate a programme's impact when unobservable factors included in the error term of the regression are related to participation. ${ }^{2}$ To apply it, an exogenous variable must be found that affects participation in the programme but that is not correlated with other variables which may affect the result. Under these conditions, the technique produces consistent estimates of the programme's impact. Specifically, this study takes advantage of the fact that social organizations require Internet access for the online application process and, in addition, some approved projects have not been implemented or completed because the social organizations responsible have had difficulties in filling out the regular expenses declaration online that is required under the terms of the grant.

Using instrumental variables in studies that refer to an environmental issue is not new (see Frankel and Rose, 2005; Jeffords and Minkler, 2016; Sims, 2010; Lin and Liscow, 2013; Anger and Oberndorfer, 2008). However, a literature review reveals that this is the first study in which an ex post evaluation has been undertaken of an environment-improvement programme based on initiatives that promote education and community participation. Thus, determining the programme's effectiveness will provide evidence to justify whether it should be pursued in Chile or modified, while at the same time it could have implications for programmes that foster community-based environmental initiatives in other countries.

\section{Background to the Environmental Protection Fund (FPA) and available data}

\section{Description of the programme}

The Environmental Protection Fund (FPA) is a programme developed by the Ministry of the Environment of Chile, the purpose of which is to finance, fully or partially, citizen initiatives, including communityor association-based projects, that seek to protect or restore the environment, promote sustainable development, preserve nature or conserve environmental heritage. The core principles of selected projects, which last a maximum of 11 months, should be to raise greater public awareness and appreciation of the environment, and promote environmental education and citizen participation.

The Fund finances projects covering multiple environmental issues, so no single outcome indicator can be applied to all projects. Specifically, initiatives financed by FPA may focus on composting, energy efficiency, climate change, decontamination and biodiversity conservation, among other issues.

The programme's target population are social organizations that submit environment-related projects and meet the requirements established in the Fund's rules. However, organizations' projects are chosen on the basis of the sum of money required for each project and the total amount available each year.

The programme's annual budget is one of the largest overseen by the Ministry of the Environment of Chile, so there is growing concern about ensuring the Fund's effectiveness. However, neither of the previous two evaluations have been able to describe the counterfactual scenario adequately, so it has not been possible to identify the programme's causal impact (Mardones, 2015).

\section{Available data}

An ex post impact evaluation can be greatly affected by data availability, in terms of both time and cost. For this reason, this study uses data from the National Socioeconomic Survey (CASEN) 2013 (Ministry of Social Development, 2013), which include individual-level information on the perception of environmental

\footnotetext{
2 These unobservable factors are typically associated with the motivation or cost-benefit analysis carried out by each unit to determine participation.
} 
quality and involvement in social organizations, among many other variables. Specifically, information on various environmental problems are recorded in this survey under the variables of perception of noise pollution; air pollution; water pollution; visual pollution; litter and dirt; odour pollution; contamination from landfill sites close to residential areas; contamination owing to the failure of wastewater systems; pollution caused by stray dogs; and pests. For example, of those surveyed, $20.7 \%$ said that noise pollution was a problem, $17.4 \%$ that air pollution was an issue and $30.2 \%$ that pollution caused by stray dogs was a problem, while $30.7 \%$ said that they did not have any pollution problems.

To carry out the ex post evaluation, it would have been ideal to have information on changes in the perceptions of those communities that benefited from each of the projects. However, the data from the CASEN 2013 survey (Ministry of Social Development, 2013) only indicate whether individuals were involved in social organizations, ${ }^{3}$ but not if they were involved in organizations that received FPA funding. Consequently, an alternative method for establishing the effect funded projects had on the community is to carry out analysis at the level of the smallest administrative district, the comuna, not the individual level. To do this, the average is calculated of the indicator of perception of environmental quality of all survey respondents in the same district (the average sample size per district is around 670 people). Obviously, this makes it difficult to identify the impact of community-based environmental initiatives, but it could also be argued that if the proposed methodology does reveal an impact, then the specific effect on the local community that benefited from a project must have been reasonably significant to affect the average perception of the entire population of the district.

Meanwhile, the Ministry of the Environment of Chile has a database of the projects that were awarded FPA financing in 2013. According to official figures, 190 projects were selected, of which $13.7 \%$ were not completed. Applications covered nine environmental lines of action, although most of the projects focused on the areas of "climate change and environmental decontamination" and "biodiversity conservation" (see table 1). The average number of FPA projects per district was 0.48 .

Table 1

Chile: projects financed by the Environmental Protection Fund (FPA), by lines of action, 2013 (Number of projects)

\begin{tabular}{lccc}
\hline \multirow{2}{*}{ Line of action } & \multicolumn{3}{c}{ Selected projects } \\
\cline { 2 - 4 } & Finalized & Not finalized & Total \\
\hline Activities to disseminate and promote environmental networks & 9 & 1 & 10 \\
\hline Production activities consistent with sustainable development & 5 & 2 & 7 \\
\hline Climate change and environmental decontamination & 65 & 7 & 72 \\
\hline Biodiversity conservation & 34 & 4 & 38 \\
\hline Creating, maintaining and strengthening of environmental networks & 15 & 5 & 18 \\
\hline Energy efficiency and non-conventional renewable energies & 14 & 4 & 5 \\
\hline Waste management and restoration of spaces & 4 & 1 & 12 \\
\hline Sharing of experiences related to environmental actions & 7 & 1 & 190 \\
\hline Sustainable management of natural resources & 11 & 1 & 26 \\
\hline Total
\end{tabular}

Source: Ministry of the Environment of Chile [online] http://www.fpa.mma.gob.cl/busqueda/busquedaPublica.php.

To define each of the districts, explanatory variables are included, constructed from the average values of the individual data taken from the CASEN 2013 survey. ${ }^{4}$ These variables are per capita income; the proportion of rural areas; the proportion of indigenous peoples; the proportion of the working population; the proportion of social organizations; the proportion of the labour force associated

3 Involvement in social organizations is low in Chile, as $74.4 \%$ of those surveyed are not involved in any type of organization.

4 Using the average value at the individual level in each district of the country. 
with natural-resource-intensive production activities; and the number of FPA-financed projects per 1,000 inhabitants (endogenous explanatory variable). Projects lasted an average of 8.6 months and had to be completed before 30 November 2013, at the latest (see figure 1). ${ }^{5}$ Meanwhile, the CASEN 2013 survey data were collected between November 2013 and January 2014, so it is expected a priori that the perception of the positive effects of environmental initiatives are more likely to have been captured in later surveys. Consequently, the dichotomous variable, "date", is included and given the value 1 if the majority of the individual surveys for a particular district were carried out in 2014.

Figure 1

Chile: month in which projects awarded grants by the Environmental Protection Fund (FPA) began and ended, 2013

(Number of projects)

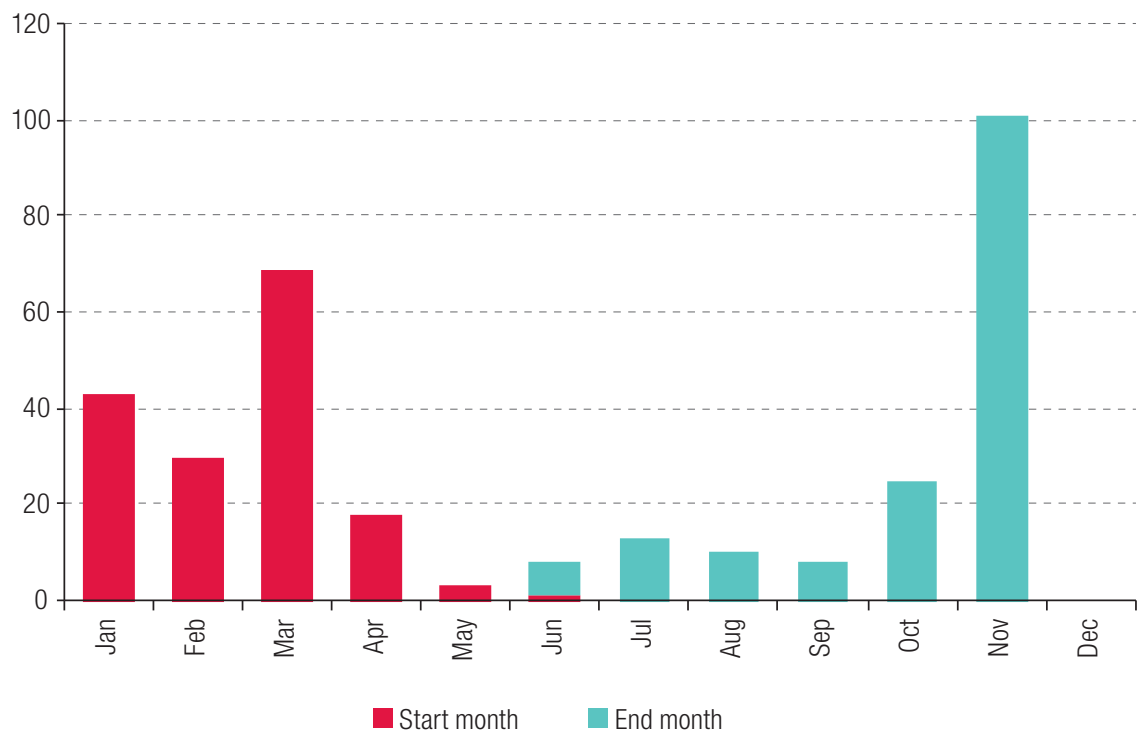

Source: Prepared by the author.

High-profile community-based interventions, such as talks, workshops and infrastructure installation, are undertaken in the early stages of the vast majority of projects. Many projects also include dissemination activities that are carried out in the final stages of the implementation timetable, once the environmental intervention has been completed. Therefore, it seems reasonable to think that, if the number of FPA-financed projects carried out in 2013 per 1,000 inhabitants is used as the treatment variable, communities can perceive projects' short-term effects before the completion date, which means that CASEN 2013 survey data can capture changes in environmental perceptions even if the data were collected between November 2013 and January 2014. However, as the effects of some projects may not have been captured by the environmental perceptions of the entire population of a district in that short period, it was decided to evaluate the long-term effects using the treatment variable "number of FPA-funded projects carried out in 2012 per 1,000 inhabitants".

The instrumental variables included in the regressions are the proportion of people who complete formalities over the Internet; the proportion of people who search for information using the Internet;

\footnotetext{
5 However, given the need to follow up on some projects, a new line of action was added to FPA in 2017, under the tender for sustainable projects (Concurso Proyectos Sostenibles), which sought to finance sustainable, association- or community-based initiatives that would help to improve the environmental quality of the area, raise greater public awareness and appreciation of the environment, and include and promote environmental education and citizen participation. Funding was capped at 30 million pesos and the projects had to last at least 18 months, until 30 November 2018 (see [online] http://www.fpa.mma. gob.cl/concurso-proyecto-sostenible.php). It is hoped that, as a result of this initiative, these high-quality projects will eventually become self-sufficient.
} 
and the proportion of the population with access to electricity in each district (see table 2). All these variables are presumably related to the fact that more FPA projects are carried out in one district and it is quite plausible that they are not related to the perception of environmental quality, so a priori they can be considered valid instruments. According to the FPA rules, the application and regular expense reports must be done online, which acts as a major barrier for some communities in districts with low levels of connectivity that wish to apply for the programme.

Table 2

Description of the statistical variables at the district level

\begin{tabular}{|c|c|c|c|c|c|c|}
\hline Variable & Description & Observations & Average & $\begin{array}{l}\text { Standard } \\
\text { deviation }\end{array}$ & Minimum & Maximum \\
\hline \multicolumn{7}{|l|}{ Dependent variables } \\
\hline environment1 & $\begin{array}{l}\text { Percentage of the population with problems } \\
\text { due to noise pollution }\end{array}$ & 324 & 0.1546 & 0.1210 & 0.0000 & 0.7118 \\
\hline environment2 & $\begin{array}{l}\text { Percentage of the population with problems } \\
\text { due to air pollution }\end{array}$ & 324 & 0.1560 & 0.1365 & 0.0000 & 0.7487 \\
\hline environment3 & $\begin{array}{l}\text { Percentage of the population with problems } \\
\text { due to water pollution }\end{array}$ & 324 & 0.0685 & 0.0866 & 0.0000 & 0.5804 \\
\hline environment4 & $\begin{array}{l}\text { Percentage of the population with problems } \\
\text { due to visual pollution }\end{array}$ & 324 & 0.0246 & 0.0383 & 0.0000 & 0.2882 \\
\hline environment5 & $\begin{array}{l}\text { Percentage of the population with problems } \\
\text { due to litter and dirt }\end{array}$ & 324 & 0.1397 & 0.0992 & 0.0000 & 0.4706 \\
\hline environment6 & $\begin{array}{l}\text { Percentage of the population with problems } \\
\text { due to odour pollution }\end{array}$ & 324 & 0.1748 & 0.1203 & 0.0000 & 0.7529 \\
\hline environment7 & $\begin{array}{l}\text { Percentage of the population with problems } \\
\text { due to contamination from landfill sites close } \\
\text { to residential areas }\end{array}$ & 324 & 0.0480 & 0.0466 & 0.0000 & 0.2996 \\
\hline environment8 & $\begin{array}{l}\text { Percentage of the population with problems } \\
\text { due to contamination owing to the failure } \\
\text { of wastewater systems }\end{array}$ & 324 & 0.0430 & 0.0476 & 0.0000 & 0.3264 \\
\hline environment9 & $\begin{array}{l}\text { Percentage of the population with problems } \\
\text { due to pollution caused by stray dogs }\end{array}$ & 324 & 0.2781 & 0.1418 & 0.0000 & 0.7703 \\
\hline environment10 & $\begin{array}{l}\text { Percentage of the population with problems } \\
\text { due to pests }\end{array}$ & 324 & 0.1069 & 0.0834 & 0.0000 & 0.3878 \\
\hline \multicolumn{7}{|l|}{ Explanatory variables } \\
\hline numberfpa & $\begin{array}{l}\text { Number of FPA-financed projects in } 2013 \\
\text { per } 1000 \text { inhabitants }\end{array}$ & 324 & 0.0408 & 0.2923 & 0.0000 & 5.0505 \\
\hline numberfpa t-1 & $\begin{array}{l}\text { Number of FPA-financed projects in } 2012 \\
\text { per } 1000 \text { inhabitants }\end{array}$ & 324 & 0.0473 & 0.2534 & 0.0000 & 3.3670 \\
\hline fpaspending & $\begin{array}{l}\text { Spending on FPA-financed projects in } 2013 \\
\text { per } 1000 \text { inhabitants (pesos) }\end{array}$ & 324 & 500669 & 4057635 & 0.0000 & $7.10 \mathrm{E}+07$ \\
\hline percapincome & Per capita income of the district (pesos) & 324 & 208551 & 108836 & 97079 & 1110263 \\
\hline rural & $\begin{array}{l}\text { Percentage of the population living in rural areas } \\
\text { in the district }\end{array}$ & 324 & 0.3492 & 0.2816 & 0.0000 & 1.0000 \\
\hline work & Percentage of the district's population who work & 324 & 0.3914 & 0.0571 & 0.2257 & 0.6283 \\
\hline socialorganization & $\begin{array}{l}\text { Percentage of the district's population who are } \\
\text { involved in social organizations }\end{array}$ & 324 & 0.1244 & 0.0821 & 0.0124 & 0.6152 \\
\hline naturalresources & $\begin{array}{l}\text { Percentage of workers in activities associated } \\
\text { with natural resources in the district }\end{array}$ & 324 & 0.1072 & 0.0711 & 0.0000 & 0.3377 \\
\hline indigenous & $\begin{array}{l}\text { Percentage of the district's population who are } \\
\text { indigenous peoples }\end{array}$ & 324 & 0.1326 & 0.1828 & 0.0000 & 0.9611 \\
\hline date & $\begin{array}{l}\text { Percentage of surveys in the district that were } \\
\text { undertaken mostly in } 2014\end{array}$ & 324 & 0.2624 & 0.4406 & 0.0000 & 1.0000 \\
\hline \multicolumn{7}{|c|}{ Instrumental variables } \\
\hline electricity & $\begin{array}{l}\text { Percentage of the district's population who have } \\
\text { access to electricity }\end{array}$ & 324 & 0.9912 & 0.0203 & 0.7980 & 1.0000 \\
\hline formalitiesinternet & $\begin{array}{l}\text { Percentage of the district's population who } \\
\text { complete formalities over the Internet }\end{array}$ & 324 & 0.0683 & 0.0620 & 0.0000 & 0.4357 \\
\hline informationinternet & $\begin{array}{l}\text { Percentage of the district's population who } \\
\text { search for information using the Internet }\end{array}$ & 324 & 0.3972 & 0.1166 & 0.1482 & 0.8577 \\
\hline
\end{tabular}

Source: Prepared by the author, on the basis of Ministry of Social Development, "Resultados Encuesta CASEN 2013" [online] http://observatorio.ministeriodesarrollosocial.gob.cl/casen-multidimensional/casen/casen_2013.php, and the Ministry of the Environment of Chile [online] http://www.fpa.mma.gob.cl/busqueda/busquedaPublica.php. 
The reason why this study includes all these explanatory variables is because, although to date there has not been a paper that evaluated community-based environmental initiatives using quantitative ex post evaluation techniques, some relatively similar studies have applied traditional econometric methods. A summary of these studies is presented in table A1.1 in the annex, which shows that there is no standard set of explanatory variables that are commonly used in quantitative assessments of environmental initiatives. Instead, each study uses a set of variables that are contingent on data availability and variables that intuitively explain the behaviour of the dependent variable. Therefore, it is not surprising that this paper does not discuss a theoretical model that establishes a relationship between the perception of environmental quality and the explanatory variables, or between the number of environmental projects and the instrumental variables.

Nevertheless, one can intuitively infer reasons why the perception of environmental quality could depend on some of the district's features. For example, according to the environmental Kuznets curve, perception of environmental quality should vary with the community's per capita income; the environmental quality should be better in districts where a higher percentage of the population live in rural areas; greater economic activity would be expected in districts where a higher percentage of the population is economically active, which could create environmental pressures; greater concern for social issues, including environmental matters, would be expected in districts where a higher percentage of the population are involved in social organizations; increased environmental pressure or, alternatively, greater concern for the sustainable management of natural resources would be expected in districts with a higher percentage of workers in activities associated with those resources; and greater concern for being environmentally friendly would be expected in districts where a higher percentage of the population are indigenous peoples. Meanwhile, the percentage of surveys that were carried out at the end of 2013 in the district could be negatively related to the perception of environmental improvement resulting from FPA projects, since the community has had less time to perceive its effects, compared to communities surveyed in January 2014.

Furthermore, it could also be argued that the instrumental variables (access to electricity, carrying out formalities over the Internet and searching for information using the Internet) are related to the endogenous explanatory variable "number of FPA-funded projects in 2013 per 1,000 inhabitants". In this regard, according to the Ministry of the Environment staff responsible for the FPA programme, many approved projects have not been completed owing to technical difficulties faced by the organizations implementing them when submitting monthly expenditure reports, which must be done online. Thus, it is clear that lower rates of Internet connectivity in a district mean that projects are less likely to be submitted or completed, while these same characteristics should not affect perception of environmental quality, controlling for the proportion of rural areas in the district.

\section{Methodology}

The statistical technique chosen for an ex post impact evaluation depends on data availability, the time available for the evaluation and the programme's characteristics, among other factors. A clear understanding of the programme's assignment rule is also needed to justify why a particular technique is used (Blundell and Costa Dias, 2009). Considering the data available in this case and the programme's assignment rule, the instrumental variables technique is the only option for this ex post evaluation.

The simplest way to obtain the instrumental variables estimator is to use the two-stage least squares (2SLS) method. The first step is to perform a linear regression of the variable participation in the programme, $P_{i}$, relative to instrumental variable, $Z i$, and observable characteristics, $X_{i}$. The second 
step is to perform a linear regression of the outcome variable, $Y_{i}$, relative to the values, $P_{i}$, predicted in the first step together with other observable characteristics, $X_{i}$. It is thus possible to estimate the average treatment effect, $\tau_{I V}$.

$$
\begin{gathered}
P_{i}=\lambda+\gamma \cdot Z_{i}+\delta \cdot X_{i}+u_{i} \\
Y_{i}=\alpha+\beta X_{i}+\tau_{I V} \hat{P}_{i}+\varepsilon_{i}
\end{gathered}
$$

However, the standard errors obtained using this method are not efficient, so both equations should be calculated together using maximum likelihood estimation routines.

In addition, some statistical tests are needed to support the use of instrumental variables. In particular, it must be demonstrated that the instruments used are not weak, in other words, that they have sufficient capacity to explain the behaviour of the endogenous variable associated with participation in the programme $\left(P_{i}\right)$, since if the correlation with participation is low, the deviation of the estimated treatment effect from the true effect could be considerable. An $F$ test can be used to test weak instruments; instrumental variables are deemed to be weak if the value of this test is less than 10 (Stock and Yogo, 2005). Meanwhile, in the case of multiple instruments, a $J$ test for overidentifying restrictions can be carried out to determine whether instrumental variables are (partially) exogenous.

\section{Results}

The individual regressions for each indicator of perception of environmental quality that include all the explanatory variables are set out in table 3 . The regressions included in this table are those that passed the relevant statistical tests to confirm that the instrumental variables are not weak ( $F$ test) and to check the exogeneity of the instrumental variables $(J$ test).

The results indicate that the FPA programme has only had a significant impact (at 5\%) on reducing the perception of odour pollution. Perception of the other environmental issues is not affected by the programme. These results are robust to different specifications of explanatory variables (see tables 4 and 5).

To confirm the robustness of the programme's impact in the short term, the original treatment variable was replaced with the variable "spending on FPA-financed projects in 2013 per 1000 inhabitants" at the district level. Tables 6, 7 and 8 show that, with this new treatment variable, the programme still only reduces the perception of odour pollution and that the coefficients of the other explanatory variables are also very similar to those set out in tables 3, 4 and 5 above. Thus, the estimated short-term effect is robust to different methods of measuring the treatment variable.

A comparison of the estimates set out in tables 3, 4 and 5 with those made using the number of FPA-financed projects per 1,000 inhabitants in 2012 as the treatment variable, shown in tables 9, 10 and 11 , reveals that when more time elapses before the survey of the perception of environmental improvements is carried out, this new treatment variable is significant in three environmental components. Thus, based on the information in table 9, it can be concluded that the programme's long-term benefits are greater that its short-term ones. Specifically, in the original model, which has more explanatory variables and includes the number of FPA-financed projects per 1,000 inhabitants with data from 2013, presented in table 3, the coefficient associated with the variable of perception of odour pollution (environment6) is -0.0932 , while the effect is nearly double $(-0.1768)$ with the number of FPA-financed projects per 1,000 inhabitants in 2012 and, in addition, there is also a reduction in the perception of air pollution (environment2) and the perception of pollution caused by stray dogs (environment9) by very similar magnitudes $(-0.1784$ and -0.1791$)$. These results are robust to different specifications of the explanatory variables (see tables 10 and 11). 


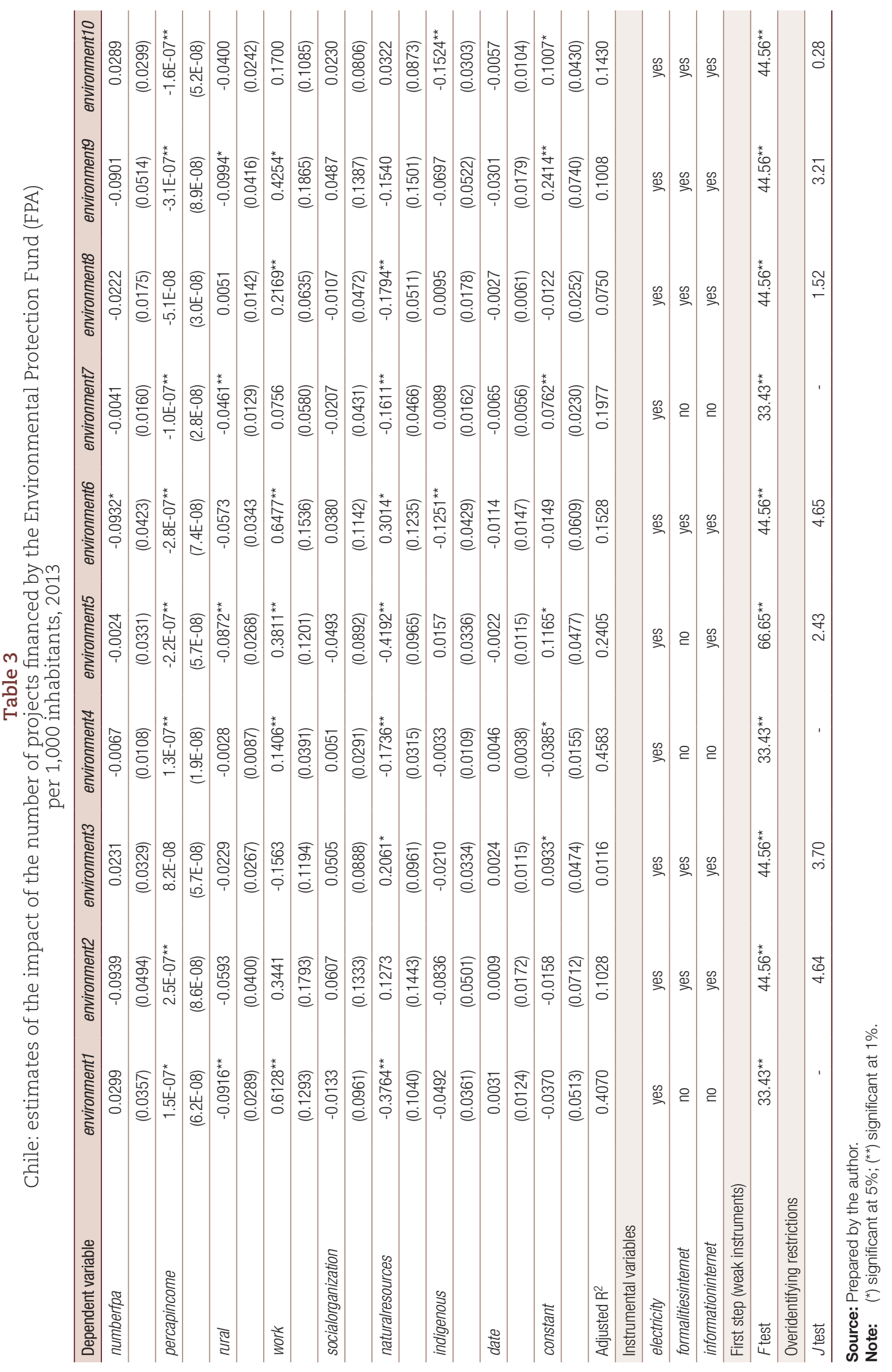




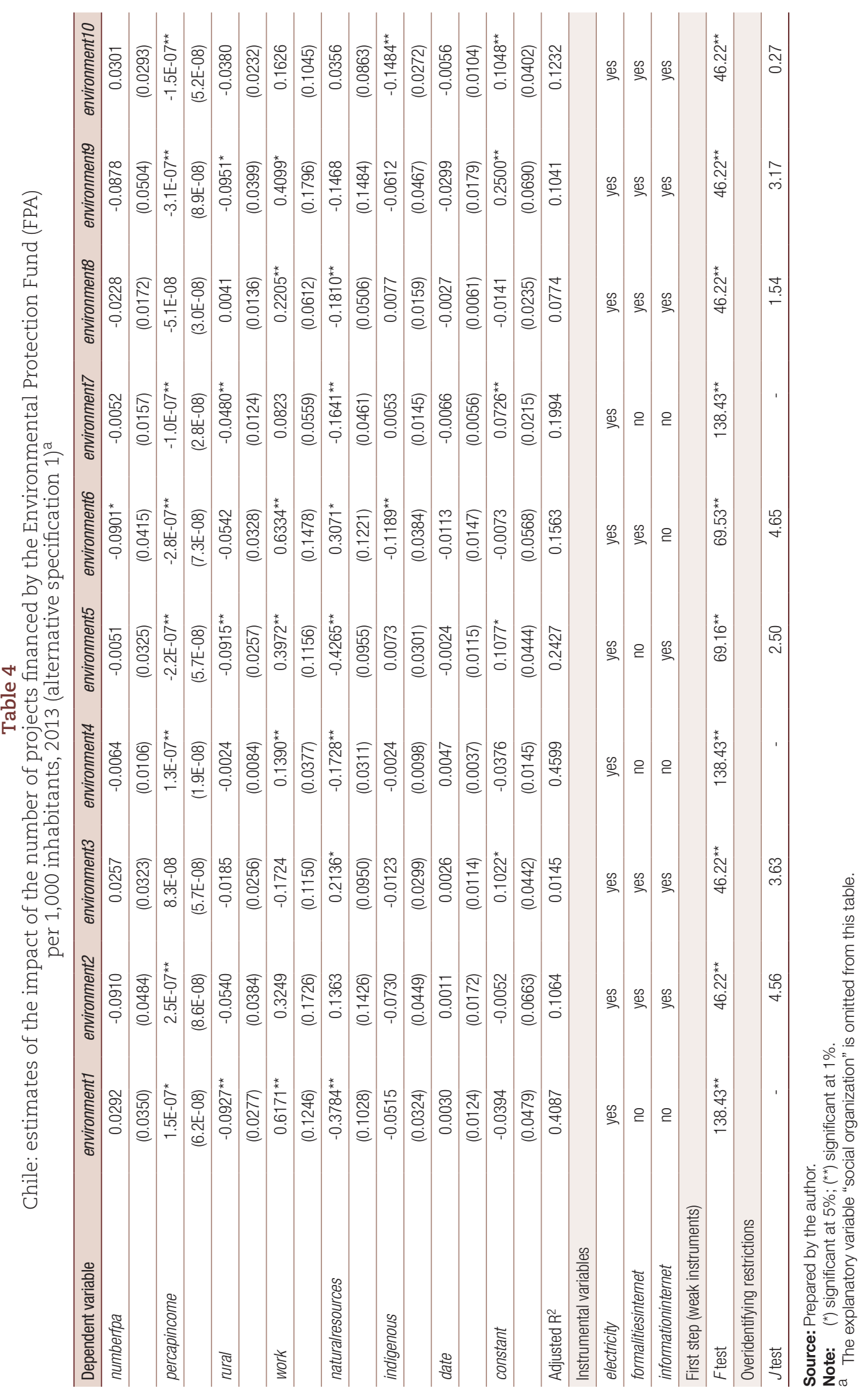




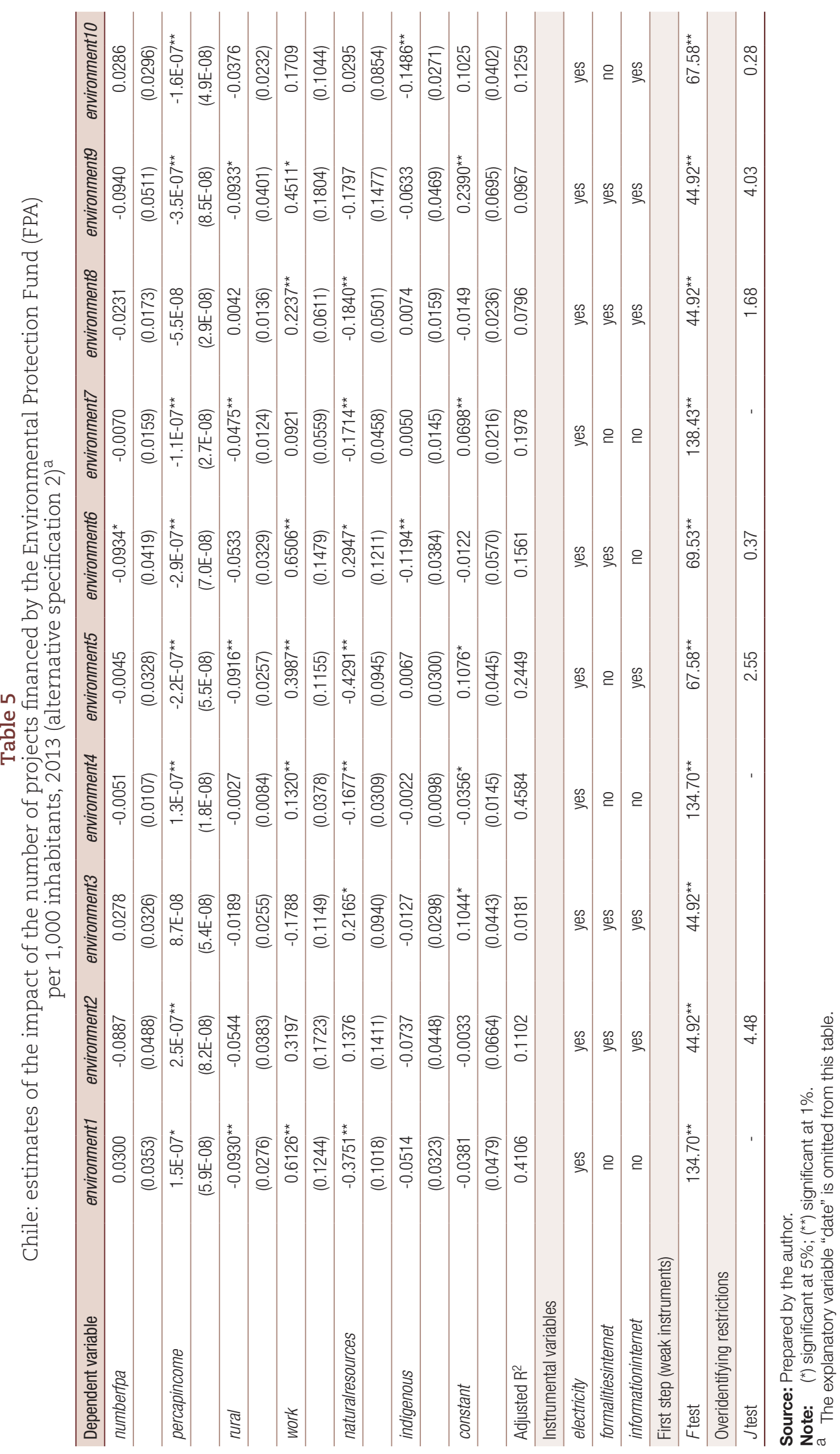


焉

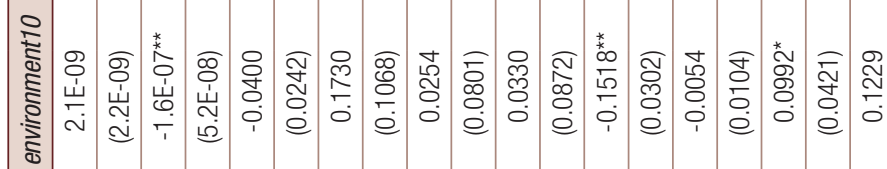

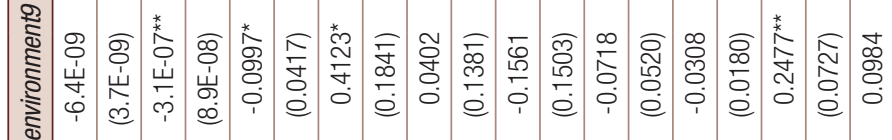

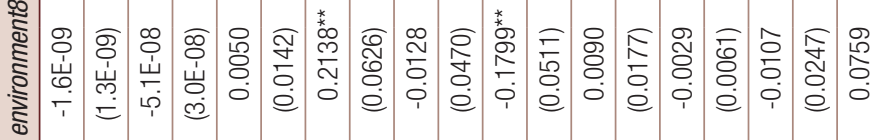

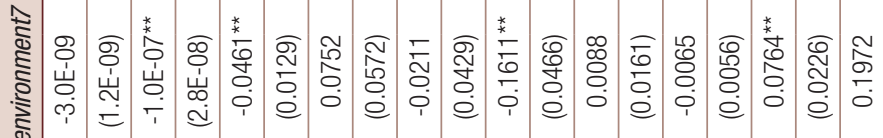

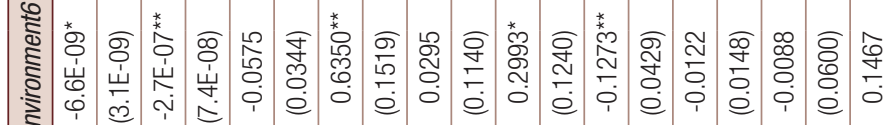

प्रm

ฮำ

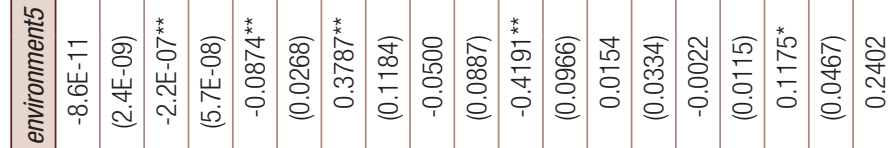

(a)

完

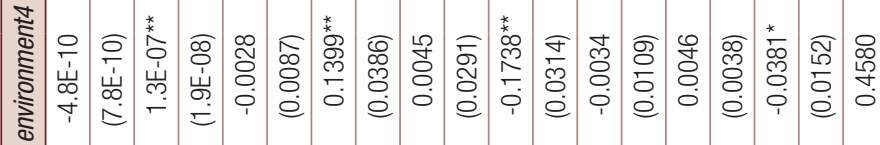

웅

.

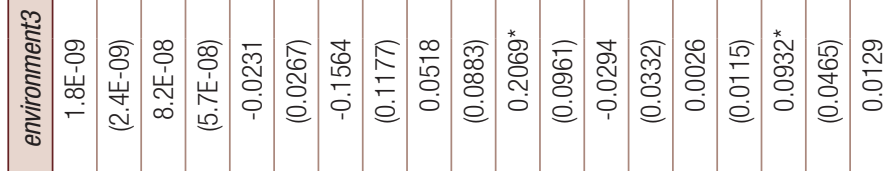

츃

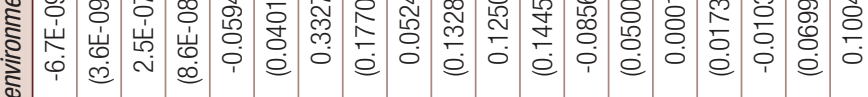

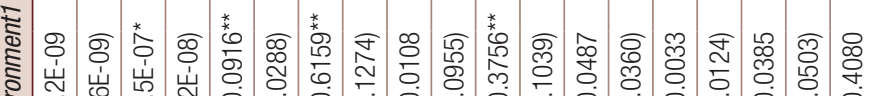

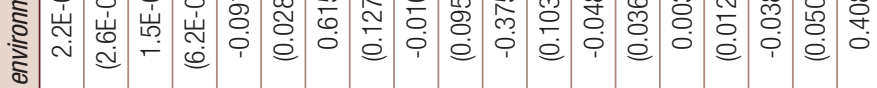

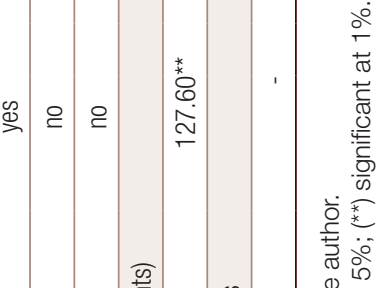

द्वृ

量高

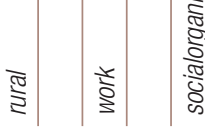

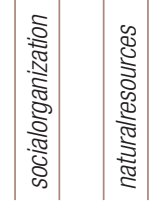

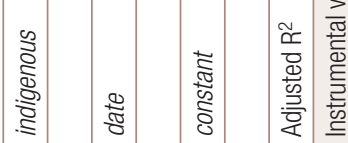

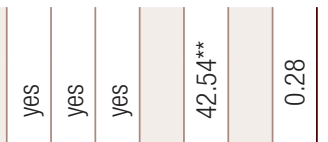

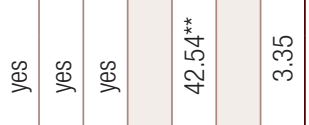

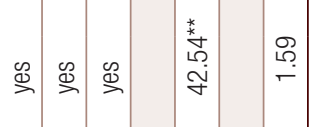

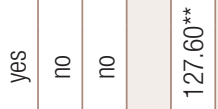

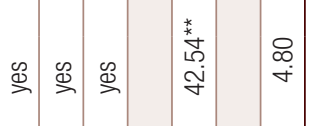

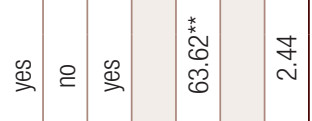

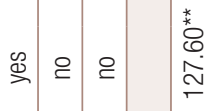

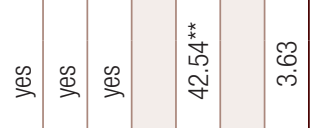

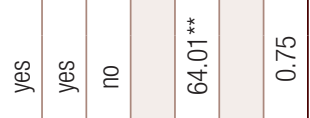

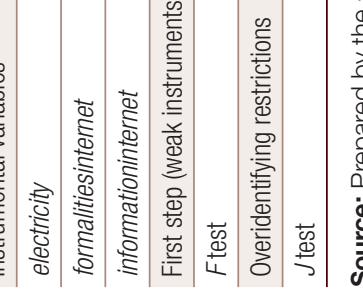

ते 듕

엏는 


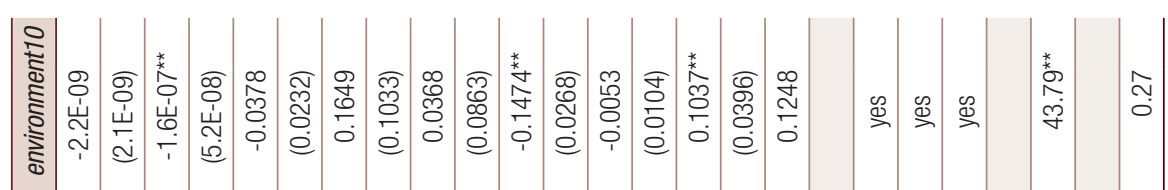

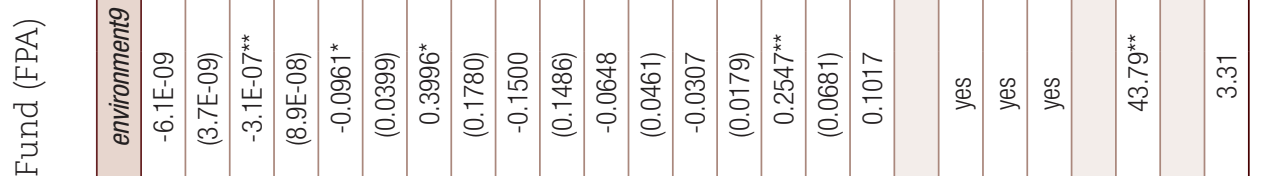

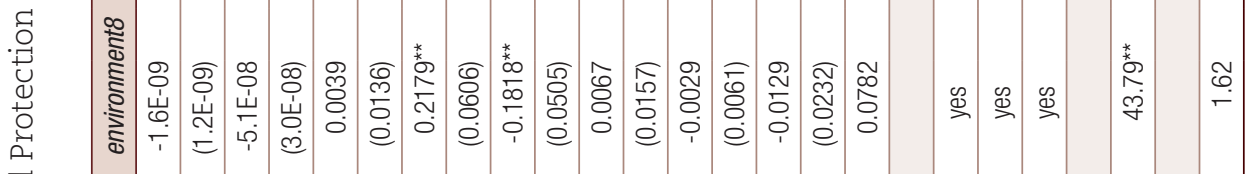
党

营

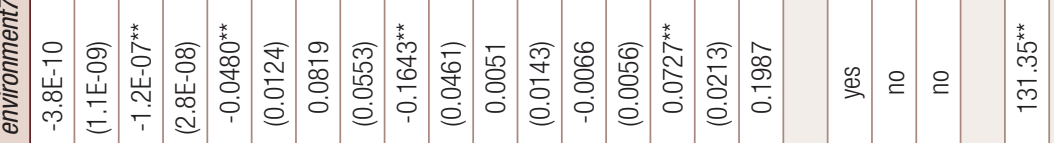

宅

(4) द्व

act

ชั

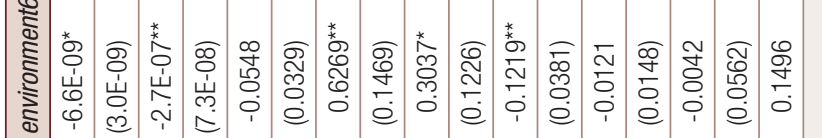

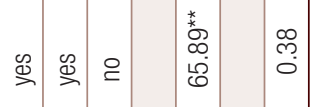
की

कृ

द्व:?

壳 द्व

डิ फ़

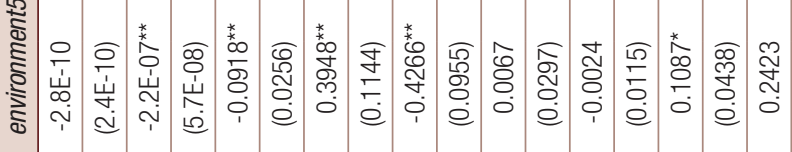

ब.

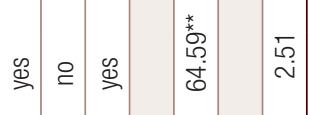

范

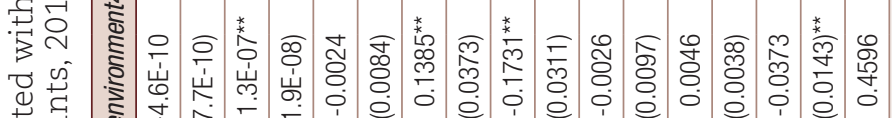

.

.

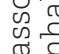

क.

.8

익

离

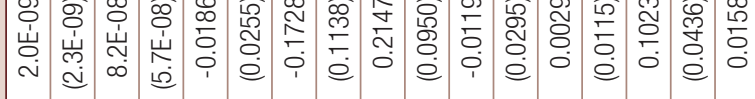

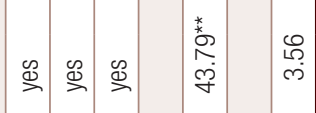

के

茨

Uั

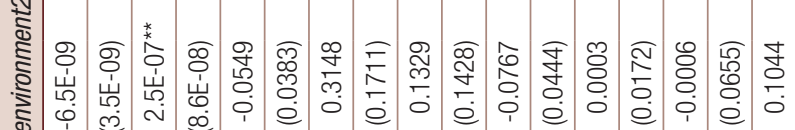

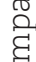

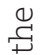

㟧

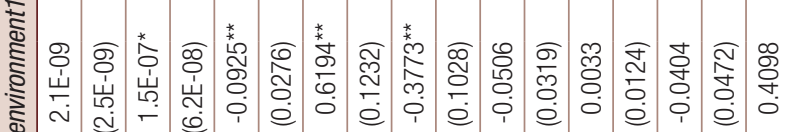

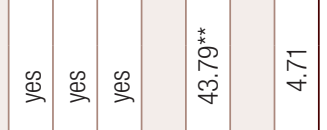

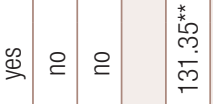

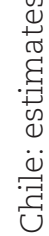

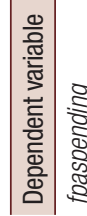

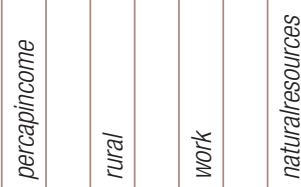

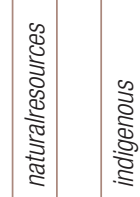

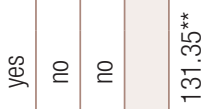

 


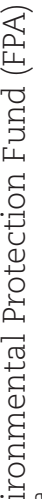

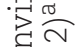

出 气ี

雪.

슨둔.

రั)

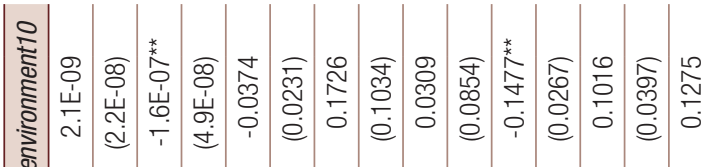

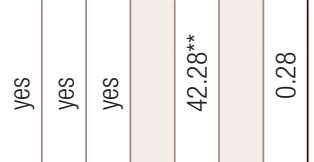

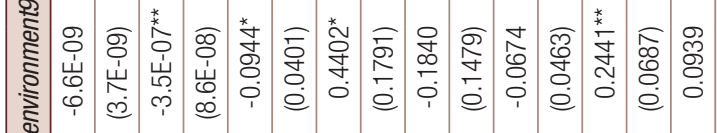

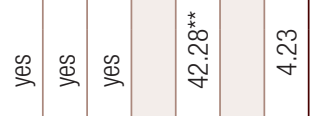

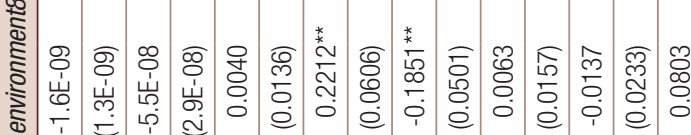

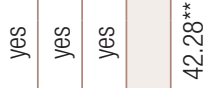

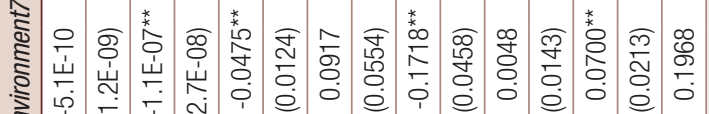

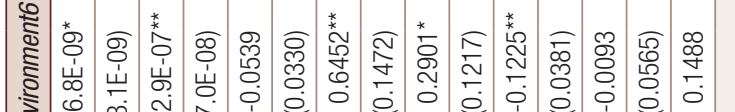

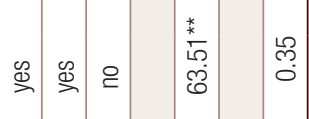

ฮี

究.

艺政

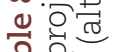

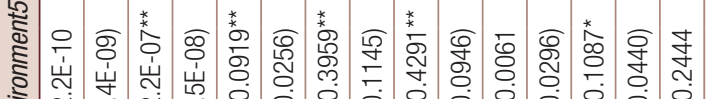

के

㑒

亲

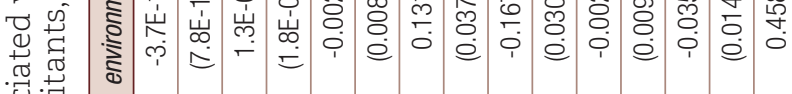

$\stackrel{\infty}{2} \cong$

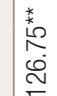

○ त्षि

D.

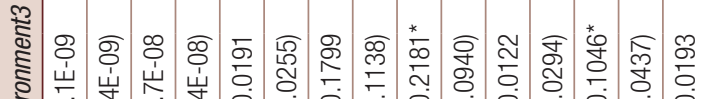

:

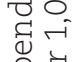

言

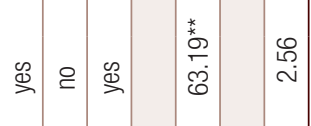

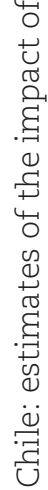

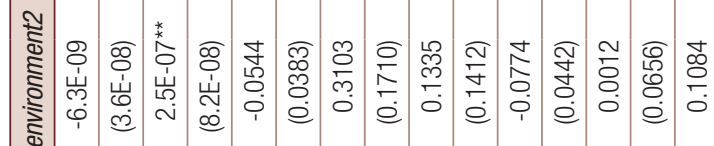

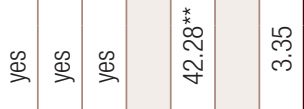

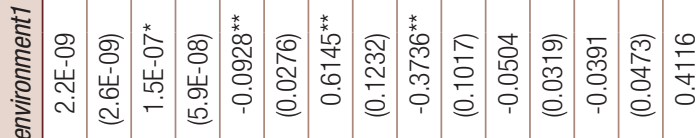

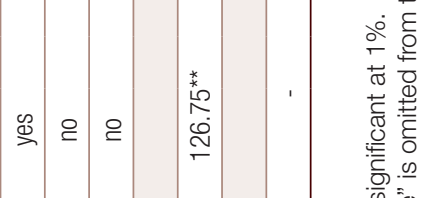

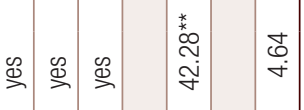

ธे

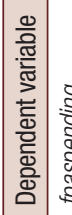

敢|

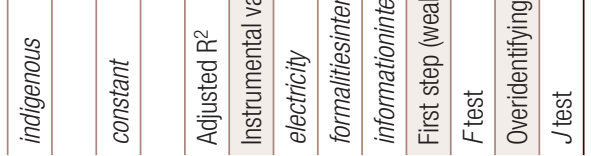

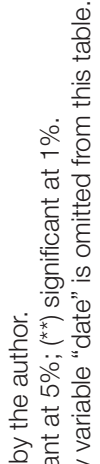

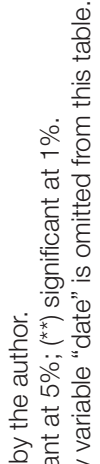

贾

$\frac{0}{0}=\frac{\pi}{2}$

苍 


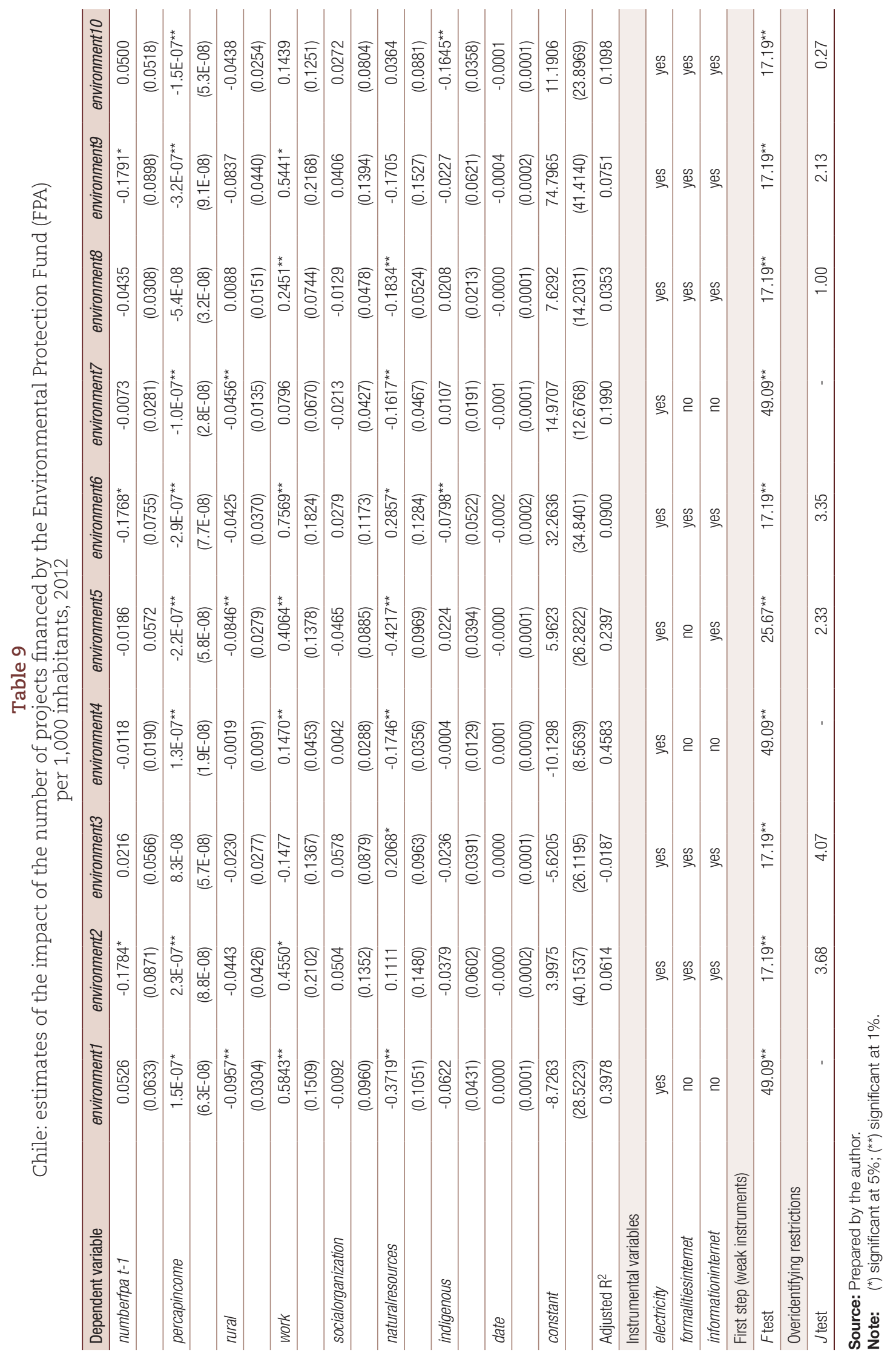




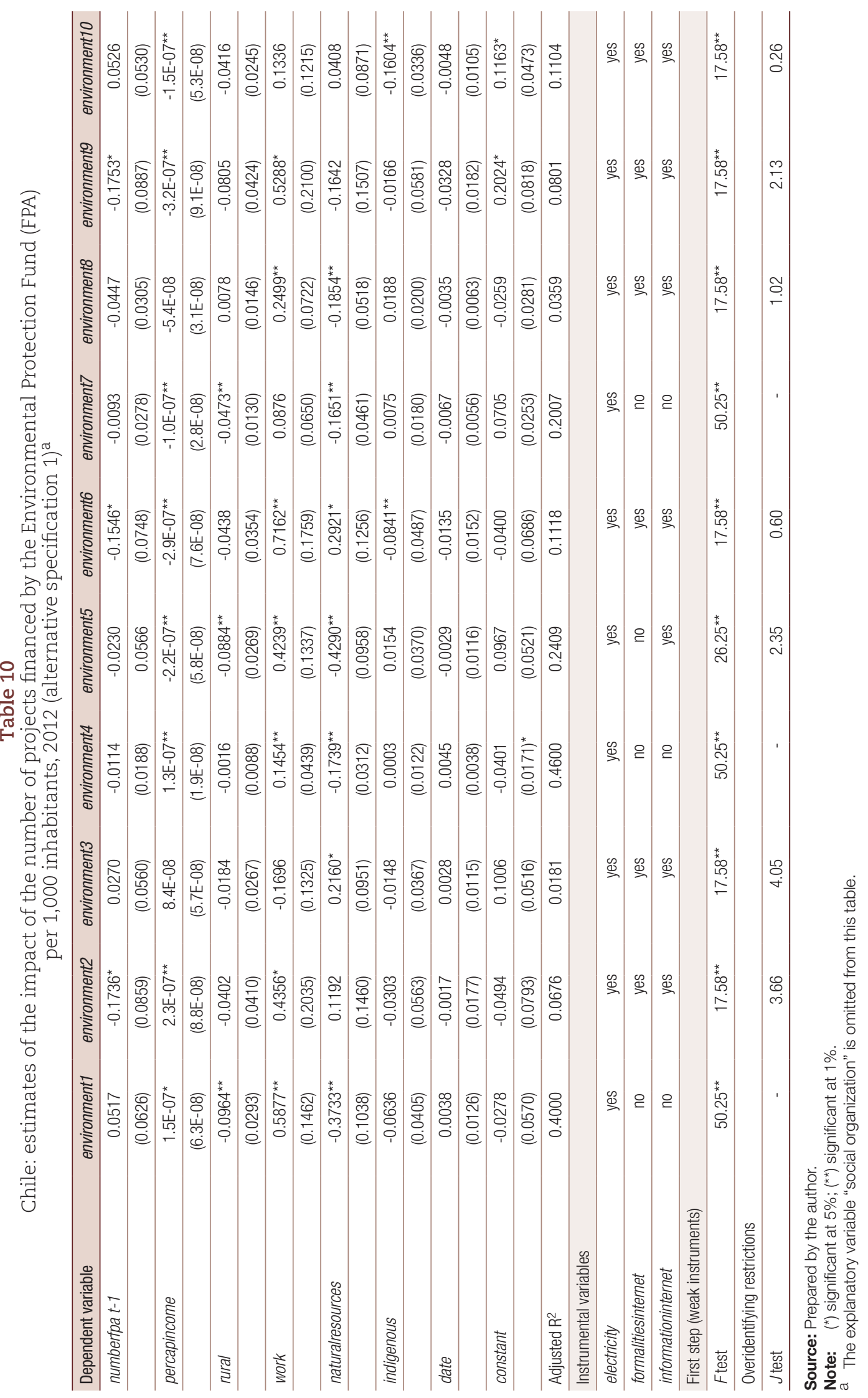




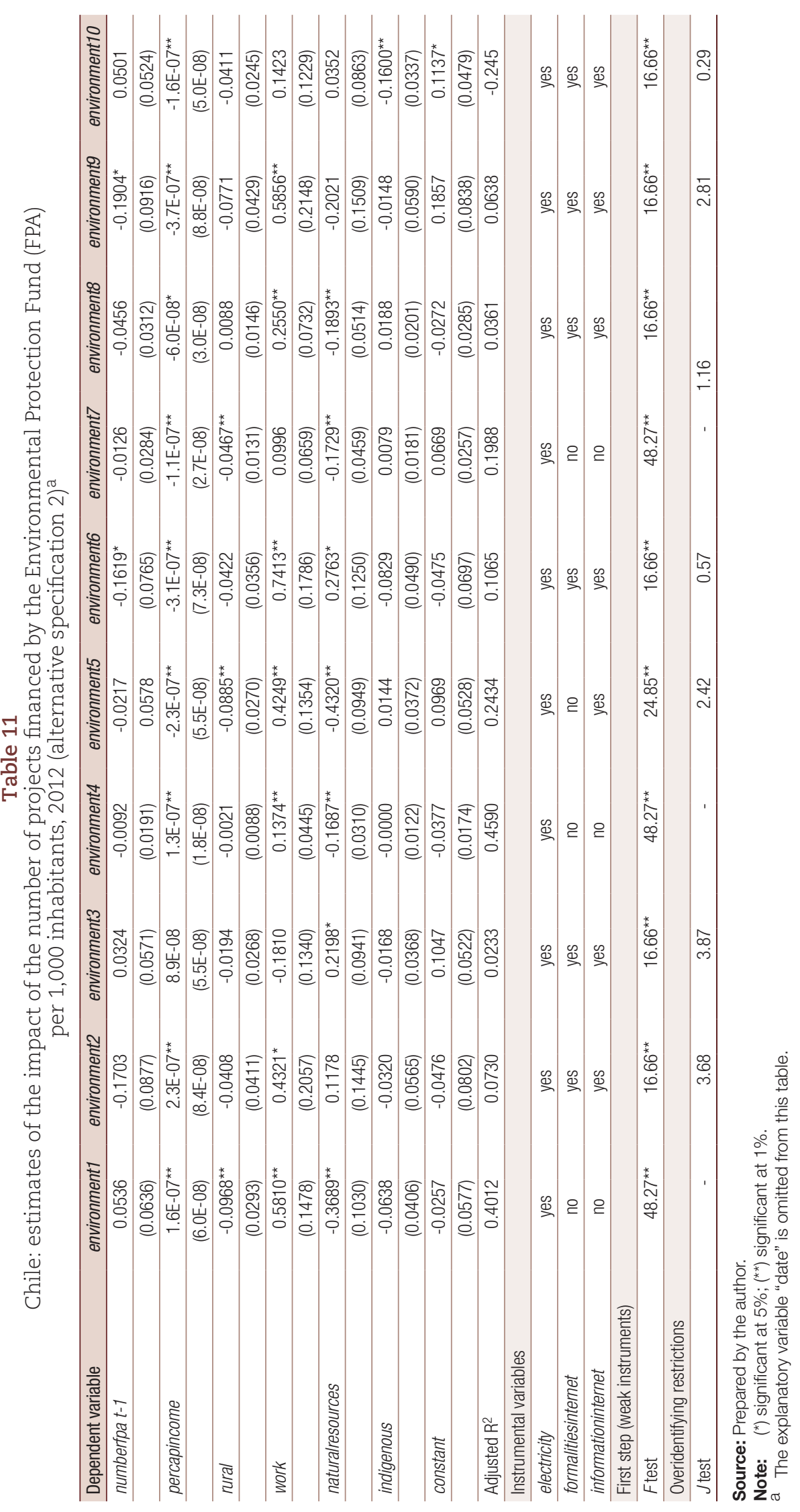


Furthermore, to validate the choice of method, it must be demonstrated that the instrumental variables are related to the endogenous explanatory variable but are not related to the dependent variable. In other words, the instruments do not need to explain the perception of environmental quality but, at the same time, the instrument must help to explain the number of FPA-financed projects or spending on FPA-financed projects per 1,000 inhabitants at the district level. As stated above, according to the Ministry of the Environment staff responsible for the programme, these projects are less likely to be completed successfully when it is difficult for project coordinators to submit expenditure reports because they do not have access to the Internet. The same argument could be used to substantiate the claim that communities without Internet access are less likely to submit projects for FPA financing. Therefore, districts where Internet access rates are higher, and whose population is more likely to carry out formalities over the Internet and to search for information using the Internet, are more likely to have a higher number of FPA-financed projects or spending associated with FPA-financed projects. Moreover, there is no apparent relationship between these instrumental variables and the perception of environmental quality variables. The results presented in tables 3-11 show that all the estimated regressions of the instrumental variables used meet the relevance test ( $F$ test) and the exogeneity test $(J$ test). It can therefore be said that the instrumental variables are suitable for determining the programme's impact.

Lastly, the effect of the other explanatory variables on the different indicators of perception of environmental quality is observed to be robust to the different specifications and treatment variables used. The higher the percentage of the population living in rural areas in a district, the lower the perception of noise pollution, litter and dirt, and contamination from landfill sites close to residential areas. The higher the percentage of workers with respect to the total population, the higher the perception of noise pollution, visual pollution, litter and dirt, odour pollution, contamination owing to the failure of wastewater systems and pollution caused by stray dogs. The higher the percentage of workers in activities associated with natural resources, the lower the perception of noise pollution, visual pollution, litter and dirt, contamination from landfill sites close to residential areas and contamination owing to the failure of wastewater systems, but also the higher the perception of water pollution and odour pollution (in all likelihood both are linked to livestock farming activities). The higher the percentage of indigenous peoples in the population of the district, the lower the perception of odour pollution and pests. Finally, the higher the per capita income in the district, the higher the perception of noise pollution, air pollution, visual pollution, but the lower the perception of litter and dirt, odour pollution, contamination from landfill sites close to residential areas, pollution caused by stray dogs and pests. Consequently, this last result indicates the existence of different Kuznets curves in Chile, depending on the type of pollution that is being analysed.

\section{Conclusions}

This study contributes empirical evidence to the existing literature on the evaluation and effectiveness of environmental policies that improve the allocation of resources in Chile. Moreover, it is innovative, as no previous studies have used quantitative ex post evaluation methodologies to determine the impact of community-based environmental initiatives in other countries.

As previous studies only use qualitative methodologies to address this problem, there is no standard set of explanatory variables that can be included in the specifications of the statistical regression models. However, a literature review was undertaken of traditional econometric methodologies applied to environmental issues, which revealed that explanatory variables are included depending on the context of each study. Consequently, the explanatory variables included in this paper were determined 
by the information available in the database of the National Socioeconomic Survey (CASEN) of 2013, which allowed each district to be typified and the perception of environmental quality in each one to be monitored.

The results of the statistical tests show that the instruments used are suitable for estimating the impacts of the programme. Therefore, it can be concluded that the programme has a significant statistical impact only on reducing the perception of odour pollution in the short term, while perception of the other nine environmental components was not affected. In the long term, the estimated impact on perception of odour pollution increased twofold, and perception of air pollution and pollution caused by stray dogs both improved by a similar magnitude. These results seem reasonable given that $39.6 \%$ of the projects selected by FPA are related to the issues of climate change and environmental decontamination. However, a large number of projects do not appear to be having any significant impact and deal with the issues of biodiversity conservation (20.7\%), environmental networks (18.9\%), energy efficiency and non-conventional renewable energies (8.5\%) and sustainable management of natural resources (6.7\%), among others. Therefore, it is natural to conclude that resources must be reallocated to improve the impact of the FPA programme.

The study's estimates also provide insight into the programme's cost-effectiveness to improve perception of different environmental components. Given that the estimated short-term effect of the variable "number of FPA-financed projects per 1,000 inhabitants" is a reduction of $9.32 \%$ in the perception of odour pollution, if the number of FPA-finance projects is increased by one in a district with an average population of 53,312 , the perception of odour pollution would be reduced by $0.175 \%$, at an average cost per project of 2.25 million pesos, so 12.9 million pesos would have to be invested in order to reduce that perception by 1 percentage point in that particular district. Applying the same procedure reveals that, in the long term, the perception of odour pollution would be reduced by $0.332 \%$, so only 6.78 million pesos would have to be invested to reduce that perception by 1 percentage point. At the same time 6.72 million pesos would have to be invested to reduce the perception of air pollution by 1 percentage point and 6.70 million pesos to reduce the perception of pollution caused by stray dogs by the same magnitude. Lastly, the cost-effectiveness indicator is infinite for each of the other environmental components, since no statistically significant impact is created.

One limitation of this study is that when a programme evaluation is carried out at the district level its impact cannot be identified accurately if the beneficiary population accounts for a relatively small percentage of the total population of the district. While it would have been ideal to have more data available to carry out the evaluation of the FPA programme, for example through the selection of a treatment group and a control group, this information has not been gathered because of the high cost of collecting data in territories far from the mainland, the difficulty of defining credible control groups and the low number of selected projects and non-selected projects, despite the fact that a study was carried out for the Ministry of the Environment which sets out the methodological design for collecting data and applying quasi-experimental and non-experimental techniques to evaluate this programme (Mardones, 2015). Consequently, this non-experimental evaluation using the instrumental variables method provides a general overview of the impact of the FPA programme at the district level and allows the programme's cost-effectiveness to be determined very cheaply, since secondary information is used, thus constituting an interesting and useful empirical application for the ex post evaluation of environmental policies. 


\section{Bibliography}

Anger, N. and U. Oberndorfer (2008), "Firm performance and employment in the EU emissions trading scheme: an empirical assessment for Germany", Energy Policy, vol. 36, No. 1, Amsterdam, Elsevier.

Bamberg, S., J. Rees and S. Seebauer (2015), "Collective climate action: determinants of participation intention in community-based pro-environmental initiatives", Journal of Environmental Psychology, vol. 43, Amsterdam, Elsevier.

Baptiste, A., C. Foley and R. Smardon (2015), "Understanding urban neighborhood differences in willingness to implement green infrastructure measures: a case study of Syracuse, NY", Landscape and Urban Planning, vol. 136, Amsterdam, Elsevier.

Blum, N. (2008), "Environmental education in Costa Rica: building a framework for sustainable development?", International Journal of Educational Development, vol. 28, No. 3, Amsterdam, Elsevier.

Blundell, R. and M. Costa Dias (2009), "Alternative approaches to evaluation in empirical microeconomics", Journal of Human Resources, vol. 44, No. 3, Madison, University of Wisconsin Press.

Byrne, J., A. Lo and Y. Jianjun (2015), "Residents' understanding of the role of green infrastructure for climate change adaptation in Hangzhou, China", Landscape and Urban Planning, vol. 138, Amsterdam, Elsevier.

Carrus, G. and others (2015). "Go greener, feel better? The positive effects of biodiversity on the well-being of individuals visiting urban and peri-urban green areas", Landscape and Urban Planning, vol. 134, Amsterdam, Elsevier.

Castro, A. and others (2011), "Social preferences regarding the delivery of ecosystem services in a semiarid Mediterranean region", Journal of Arid Environments, vol. 75, No. 11, Amsterdam, Elsevier.

Dennis, M. and P. James (2016), "Site-specific factors in the production of local urban ecosystem services: a case study of community-managed green space", Ecosystem Services, vol. 17, Amsterdam, Elsevier.

Derkzen, M., A. van Teeffelen and P. Verburg (2017), "Green infrastructure for urban climate adaptation: how do residents' views on climate impacts and green infrastructure shape adaptation preferences?", Landscape and Urban Planning, vol. 157, Amsterdam, Elsevier.

Eltayeb, T., S. Zailani and T. Ramayah (2011), "Green supply chain initiatives among certified companies in Malaysia and environmental sustainability: investigating the outcomes", Resources, Conservation and Recycling, vol. 55, No. 5, Amsterdam, Elsevier.

Feser, E. (2013), "Isserman's impact: quasi-experimental comparison group designs in regional research", International Regional Science Review, vol. 36, No. 1, Thousand Oaks, SAGE.

Frankel, J. and A. Rose (2005), "Is trade good or bad for the environment? Sorting out the causality", Review of Economics and Statistics, vol. 87, No. 1, Cambridge, MIT Press.

Imbens, G. and J. Wooldridge (2009), "Recent developments in the econometrics of program evaluation", Journal of Economic Literature, vol. 47, No. 1, Nashville, American Economic Association.

Jeffords, C. and L. Minkler (2016), "Do constitutions matter? The effects of constitutional environmental rights provisions on environmental outcomes", Kyklos, vol. 69, No. 2, Hoboken, Wiley.

Kang, K. and others (2012), "Consumers' willingness to pay for green initiatives of the hotel industry", International Journal of Hospitality Management, vol. 31, No. 2, Amsterdam, Elsevier.

Lin, C. and Z. Liscow (2013), "Endogeneity in the environmental Kuznets curve: an instrumental variables approach", American Journal of Agricultural Economics, vol. 95, No. 2, Oxford, Oxford University Press.

Luan, C., C. Tien and W. Chen (2016), "Which "green" is better? An empirical study of the impact of green activities on firm performance", Asia Pacific Management Review, vol. 21, No. 2, Amsterdam, Elsevier.

Mardones (2015), Guía metodológica para la evaluación ex-post de políticas ambientales, Santiago, Universidad de Concepción.

Marquart-Pyatt, S. (2012), "Contextual influences on environmental concerns cross-nationally: a multilevel investigation", Social Science Research, vol. 41, No. 5, Amsterdam, Elsevier.

Méndez-López, M. and others (2014), "Local participation in biodiversity conservation initiatives: a comparative analysis of different models in South East Mexico", Journal of Environmental Management, vol. 145, Amsterdam, Elsevier.

Ministry of Social Development (2013), "Resultados Encuesta CASEN 2013" [online] http://observatorio. ministeriodesarrollosocial.gob.cl/casen-multidimensional/casen/casen_2013.php.

Peters, M., S. Fudge and P. Sinclair (2010), "Mobilising community action towards a low-carbon future: opportunities and challenges for local government in the UK", Energy Policy, vol. 38, No. 12, Amsterdam, Elsevier. 
Pujadas, A. and A. Castillo (2007), "Social participation in conservation efforts: a case study of a biosphere reserve on private lands in Mexico", Society \& Natural Resources, vol. 20, No. 1, Abingdon, Taylor \& Francis.

Rees, J. and S. Bamberg (2014), "Climate protection needs societal change: determinants of intention to participate in collective climate action", European Journal of Social Psychology, vol. 44, No. 5, Hoboken, Wiley.

Sims, K. (2010), "Conservation and development: evidence from Thai protected areas", Journal of Environmental Economics and Management, vol. 60, No. 2, Amsterdam, Elsevier.

Stock, J. and M. Yogo (2005), "Testing for weak instruments in linear IV regression", Identification and Inference for Econometric Models: a Festschrift in Honor of Thomas Rothenberg, D. Andrews y J. Stock (eds.), New York, Cambridge University Press.

Walker, G. and P. Devine-Wright (2008), "Community renewable energy: what should it mean?", Energy Policy, vol. 36, No. 2, Amsterdam, Elsevier.

Waylen, K. and others (2010), "Effect of local cultural context on the success of community-based conservation interventions", Conservation Biology, vol. 24, No. 4, Hoboken, Wiley.

Zailani, S. and others (2015), "Green innovation adoption in automotive supply chain: the Malaysian case", Journal of Cleaner Production, vol. 108, Amsterdam, Elsevier. 


\section{Annex A1}

Table A1.1

Summary of traditional econometric methodologies to evaluate environmental initiatives

\begin{tabular}{|c|c|c|c|c|}
\hline Publication & $\begin{array}{l}\text { Country } \\
\text { or territory }\end{array}$ & Methodology & Dependent variables & Explanatory variables \\
\hline $\begin{array}{l}\text { Castro and others } \\
\text { (2011) }\end{array}$ & Spain & $\begin{array}{l}\text { Probit and multiple } \\
\text { linear regression }\end{array}$ & $\begin{array}{l}\text { Willingness to pay for the } \\
\text { maintenance of ecosystem services }\end{array}$ & $\begin{array}{l}\text { Family income, education level, area that } \\
\text { provides ecosystem services, visits to the } \\
\text { protected area }\end{array}$ \\
\hline Marquart-Pyatt (2012) & 27 countries & Multinomial logit & $\begin{array}{l}\text { Environmental threat awareness, } \\
\text { environmental efficacy and } \\
\text { willingness to pay }\end{array}$ & $\begin{array}{l}\text { Ecological footprints, ecosystem } \\
\text { well-being, sulfur dioxide emissions, } \\
\text { carbon dioxide emissions and } \\
\text { water quality }\end{array}$ \\
\hline $\begin{array}{l}\text { Baptiste, Foley and } \\
\text { Smardon (2015) }\end{array}$ & United States & Logit & $\begin{array}{l}\text { Willingness to implement green } \\
\text { infrastructure in the case study }\end{array}$ & $\begin{array}{l}\text { Green infrastructure knowledge, } \\
\text { efficacy, influence factors and } \\
\text { demographic variables }\end{array}$ \\
\hline $\begin{array}{l}\text { Byrne, Lo and Jianjun } \\
\text { (2015) }\end{array}$ & China & $\begin{array}{l}\text { Multiple linear } \\
\text { regression }\end{array}$ & $\begin{array}{l}\text { Perceived benefits of urban } \\
\text { tree planting }\end{array}$ & $\begin{array}{l}\text { Awareness of climate change, concern } \\
\text { about climate change, expected impact } \\
\text { of climate change }\end{array}$ \\
\hline $\begin{array}{l}\text { Carrus and others } \\
(2015)\end{array}$ & Italy & Factor analysis & $\begin{array}{l}\text { Biodiversity level, location } \\
\text { of green areas }\end{array}$ & $\begin{array}{l}\text { Aggregate scores of benefits and well- } \\
\text { being and perceived restorativeness score }\end{array}$ \\
\hline $\begin{array}{l}\text { Dennis and James } \\
(2016)\end{array}$ & United Kingdom & $\begin{array}{l}\text { Multiple linear } \\
\text { regression }\end{array}$ & Ecosystem service provision score & Vegetation cover, food cultivation area \\
\hline $\begin{array}{l}\text { Derkzen, Van Teeffelen } \\
\text { and Verburg (2017) }\end{array}$ & Netherlands & Multinomial logit & $\begin{array}{l}\text { Concerns about heat waves, the } \\
\text { notion of urban flooding, concern } \\
\text { about flooding }\end{array}$ & Age, education \\
\hline $\begin{array}{l}\text { Eltayeb, Zailani and } \\
\text { Ramayah (2011) }\end{array}$ & Malaysia & $\begin{array}{l}\text { Multiple linear } \\
\text { regression }\end{array}$ & $\begin{array}{l}\text { Environmental outcomes, economic } \\
\text { outcomes, cost reductions and } \\
\text { intangible outcomes }\end{array}$ & $\begin{array}{l}\text { Green purchasing, environmentally- } \\
\text { friendly design, reverse logistics }\end{array}$ \\
\hline $\begin{array}{l}\text { Kang and others } \\
\text { (2012) }\end{array}$ & United States & $\begin{array}{l}\text { Multiple linear } \\
\text { regression }\end{array}$ & $\begin{array}{l}\text { Attitude of respondents to } \\
\text { environmental concerns }\end{array}$ & $\begin{array}{l}\text { Gender, income, age, level of education, } \\
\text { civil status, work experience }\end{array}$ \\
\hline $\begin{array}{l}\text { Zailani and others } \\
\text { (2015) }\end{array}$ & Malaysia & Partial least squares & $\begin{array}{l}\text { Green innovation initiatives } \\
\text { (green product innovation, green } \\
\text { process innovation) }\end{array}$ & $\begin{array}{l}\text { Market regulations, market demand, } \\
\text { firms' green initiatives }\end{array}$ \\
\hline $\begin{array}{l}\text { Luan, Tien and Chen } \\
\text { (2016) }\end{array}$ & $\begin{array}{l}\text { Taiwan Province } \\
\text { of China }\end{array}$ & Multinomial logit & $\begin{array}{l}\text { Pollution prevention, green } \\
\text { certifications, firms' performance }\end{array}$ & $\begin{array}{l}\text { Degree of research and development, } \\
\text { degree of internationalization }\end{array}$ \\
\hline
\end{tabular}

Source: Prepared by the author.

Table A1.2

Chile: type, scope and duration of projects financed by the Environmental Protection Fund (FPA) and completed, 2013

\begin{tabular}{llr}
\hline Type of project & Scope & $\begin{array}{c}\text { Duration } \\
\text { (months) }\end{array}$ \\
\hline Environmental education & Fishing village & 6 \\
\hline Efficient management of organic waste & Fishing village & 10 \\
\hline Environmental study of wetlands & Comuna & 11 \\
\hline Environmental network of older persons & Comuna & 8 \\
\hline Assessment of solar energy and environmental education & Comuna & 10 \\
\hline Environmental education for social leaders & Comuna & 6 \\
\hline Creation of a sustainable park & Comuna & 9 \\
\hline Environmental education programme on organic agriculture & Comuna & 9 \\
\hline Preservation of endangered native species & Comuna & 6 \\
\hline Protection and conservation of wetlands & Comuna & 9 \\
\hline Eradication of exotic species & Comuna & 10 \\
\hline Virtual network of young people to care for the environment & Comuna & 10 \\
\hline Environmental education and conservation workshops & Comuna & 6 \\
\hline Creation of an environmental care demonstration centre & Comuna & 7 \\
\hline Wetland restoration & Comuna & 9 \\
\hline Waste recycling and composting & Comuna & 11 \\
\hline Green fair for sharing experiences and knowledge of environmental matters & Comuna & 8 \\
\hline Conservation of the native forest & Comuna & 11 \\
\hline
\end{tabular}


Table A1.2 (continued)

\begin{tabular}{|c|c|c|}
\hline Type of project & Scope & $\begin{array}{l}\text { Duration } \\
\text { (months) }\end{array}$ \\
\hline Environmental education & Comuna & 9 \\
\hline Strengthening the comuna's environmental network and disseminating environmental issues & Comuna & 10 \\
\hline Education and launch of a waste management and use system & Comuna & 9 \\
\hline Environmental education & Comuna & 9 \\
\hline Exchange of native species seeds and creation of a guide & Comuna & 10 \\
\hline Education and training on the efficient use of wood for heating & Comuna & 11 \\
\hline Environmental networks and ecological tours & Comuna & 6 \\
\hline Environmentally-friendly and efficient consumption workshops & Comuna & 9 \\
\hline University network for sustainable development & Comuna & 10 \\
\hline Environmental workshops, walks and fairs & Comuna & 9 \\
\hline Environmental workshops & Comuna & 10 \\
\hline Workshops and promotion of a bird watching festival & Comuna & 10 \\
\hline Environmental talks and recycling campaigns & Comuna & 9 \\
\hline Establishment of a community centre for environmental education and training local monitors & Comuna & 11 \\
\hline Installation of infrastructure to minimize solid waste and workshops & Comuna & 8 \\
\hline Training on environmental issues for social organizations' leaders & Comuna & 6 \\
\hline Development of a workshop for environmentally-friendly training and art tours & Comuna & 6 \\
\hline Environmental education and training workshops & Comuna & 11 \\
\hline $\begin{array}{l}\text { Creation of a physical space for environmental education focused on wetlands } \\
\text { and conservation }\end{array}$ & Comuna & 11 \\
\hline Environmental workshop and preparation of eight television news bulletins & Comuna & 9 \\
\hline Preparation of environmental studies and ecotourism training & Comuna & 10 \\
\hline National meeting on protecting forestry and agricultural biodiversity & Comuna & 6 \\
\hline Recycling in educational establishments & Comuna & 8 \\
\hline Environmental education for conservation & Comuna & 9 \\
\hline Compiling information on the coastal area & Comuna & 8 \\
\hline Campaign to assess and care for the coastal sector & Comuna & 7 \\
\hline Establishment of recycling points and making them ready (recycling and composting) & Comuna & 9 \\
\hline Free environmental education cycling tours for citizens & Comuna & 6 \\
\hline Establishment of the Environmental Education and Innovation Centre & Comuna & 7 \\
\hline Reforestation with native tree species in areas vulnerable to erosion & Comuna & 7 \\
\hline Development of a virtual network for citizens organizations on environmental issues & Comuna & 9 \\
\hline $\begin{array}{l}\text { Establishment of a workspace to collect, analyse and disseminate bioindicators } \\
\text { for conservation }\end{array}$ & Comuna & 10 \\
\hline Creation of a network of kindergartens to promote recycling and repurposing of waste & Comuna & 8 \\
\hline Design, development and management of a citizen environmental management plan & Comuna & 10 \\
\hline Determining human impact of mining and livestock farming on national reserve & Comuna & 6 \\
\hline Use of non-conventional renewable energies & Indigenous community & 9 \\
\hline Installation of sustainable hot water systems & Indigenous community & 7 \\
\hline Installation of sustainable hot water systems & Indigenous community & 10 \\
\hline Installation of solar energy systems & Indigenous community & 8 \\
\hline Protection of watershed and channelling water to the basin & Indigenous community & 7 \\
\hline Installation of solar energy systems & Indigenous community & 6 \\
\hline Protection of cultural heritage related producing medicinal herbs & Indigenous community & 9 \\
\hline Reviving traditional flora & Indigenous community & 10 \\
\hline Environmental restoration of the sector for education on Mapuche ancestral culture & Indigenous community & 9 \\
\hline Construction of family vegetable patches to preserve species & Indigenous community & 7 \\
\hline Installation of renewable energy systems & Indigenous community & 7 \\
\hline Installation of solar panels & Indigenous community & 10 \\
\hline Installation of renewable energy systems & Indigenous community & 11 \\
\hline Promoting understanding of biodiversity from the Mapuche worldview & Indigenous community & 8 \\
\hline Closure and reforestation of degraded sites with native species and medicinal herbs & Indigenous community & 6 \\
\hline Closure and reforestation of degraded sites with native species & Indigenous community & 8 \\
\hline
\end{tabular}


Table A1.2 (continued)

\begin{tabular}{|c|c|c|}
\hline Type of project & Scope & $\begin{array}{l}\text { Duration } \\
\text { (months) }\end{array}$ \\
\hline Environmental training workshops with an intercultural approach & Indigenous community & 7 \\
\hline Management of organic and inorganic waste & Indigenous community & 11 \\
\hline Forest restoration and protection, with a video record & Indigenous community & 10 \\
\hline Installing and encouraging the use of solar energy systems in offices & Indigenous community & 10 \\
\hline Building a ruca (traditional Mapuche house) and installing waste management containers & Indigenous community & 9 \\
\hline Installation of solar panels & Indigenous community & 11 \\
\hline Promotion of ethno-tourism programme and development of an eco-park & Indigenous community & 9 \\
\hline Construction of a greenhouse and composting centre & Indigenous community & 9 \\
\hline Creation of a demonstration site with clean energy generation systems & Indigenous community & 8 \\
\hline Mitigating or reducing the environmental impact of pollution caused by tourists at the beach & Indigenous community & 6 \\
\hline Recovery of the native forest and its biodiversity to create a park & Indigenous community & 8 \\
\hline Installation of thermal solar system for domestic water heating & Indigenous community & 9 \\
\hline Installation of thermal solar system for domestic water heating and environmental education & Indigenous community & 9 \\
\hline Installation of thermal solar system for domestic water heating and environmental education & Indigenous community & 8 \\
\hline Agricultural crops & Educational establishment & 6 \\
\hline Water recycling to irrigate green areas & Educational establishment & 6 \\
\hline Water recycling to irrigate green areas & Educational establishment & 8 \\
\hline Marine conservation education & Educational establishment & 7 \\
\hline Environmental education to combat climate change & Educational establishment & 9 \\
\hline Solar energy demonstration module on a nature trail & Educational establishment & 9 \\
\hline Study of the climate and pollution in the comuna & Educational establishment & 9 \\
\hline Promotion local environmental management & Educational establishment & 9 \\
\hline Environmental education workshop & Educational establishment & 6 \\
\hline Environmental education & Educational establishment & 7 \\
\hline Installation of recycling and waste minimization infrastructure & Educational establishment & 8 \\
\hline Creation of an educational tool to address environmental issues & Educational establishment & 7 \\
\hline Environmental education developing activities outside the institution & Educational establishment & 8 \\
\hline Creation of an environmental education demonstration centre & Educational establishment & 9 \\
\hline Setting up of a laboratory and training for teachers, students and community members & Educational establishment & 8 \\
\hline Incentives for the use of environmentally-friendly diapers & Educational establishment & 8 \\
\hline Construction of greenhouses using plastic bottles & Educational establishment & 6 \\
\hline Installation of containers to collect rainwater to be recycled & Educational establishment & 10 \\
\hline Installation of a recycling point and environmentally-friendly plaza & Educational establishment & 9 \\
\hline Appreciation of nature through the cultivation of vegetables and medicinal herbs & Educational establishment & 7 \\
\hline Environmental education & Various educational establishments & 9 \\
\hline Theoretical and practical workshops on environmental education & Various educational establishments & 9 \\
\hline Knowledge and dissemination of endangered native species & Various educational establishments & 11 \\
\hline Network of school ecological groups & Various educational establishments & 9 \\
\hline Construction de biotopes in educational spaces & Various educational establishments & 8 \\
\hline Education on and dissemination of the National Climate Change Action Plan & Various educational establishments & 10 \\
\hline Recycling and waste reduction & Various educational establishments & 9 \\
\hline Environmental education network in schools & Various educational establishments & 9 \\
\hline Setting up forests as a "natural laboratory" for conservation & Various educational establishments & 11 \\
\hline Open air workshops and competitions & Various educational establishments & 7 \\
\hline Theatre play with an environmental protection theme & Various educational establishments & 6 \\
\hline Preparation of educational material for children on biodiversity and conservation & Various educational establishments & 9 \\
\hline Creation of a network of school ornithology groups & Various educational establishments & 8 \\
\hline Environmental education for the protection of wildlife in priority sites & Various educational establishments & 9 \\
\hline $\begin{array}{l}\text { Development of an educational game on environmental issues to be used } \\
\text { in educational centres }\end{array}$ & Various educational establishments & 11 \\
\hline Installation of thermal solar panels for hot water & Foundation & 6 \\
\hline Training on and carrying out the recycling of household waste & Neighbourhood association & 7 \\
\hline Ecological farming activities & Neighbourhood association & 8 \\
\hline
\end{tabular}


Table A1.2 (concluded)

\begin{tabular}{|c|c|c|}
\hline Type of project & Scope & $\begin{array}{l}\text { Duration } \\
\text { (months) }\end{array}$ \\
\hline Ecological activities & Neighbourhood association & 8 \\
\hline Environmental education workshops on solar energy & Neighbourhood association & 9 \\
\hline Infrastructure for and training on recycling & Neighbourhood association & 11 \\
\hline Installation of a recycling centre and environmental education workshops & Neighbourhood association & 8 \\
\hline Installation of solar cookers & Neighbourhood association & 7 \\
\hline Recycling and composting & Neighbourhood association & 9 \\
\hline Solid waste management, afforestation and creation of vegetable plots & Neighbourhood association & 10 \\
\hline Installation of hot water solar collector and photovoltaic panels & Neighbourhood association & 9 \\
\hline Self-construction of dry toilets for waste disposal & Neighbourhood association & 8 \\
\hline Installation of solar energy system & Neighbourhood association & 7 \\
\hline Production of organic foods & Neighbourhood association & 11 \\
\hline Educational farm to cultivate endemic tree species & Neighbourhood association & 9 \\
\hline Comprehensive waste management & Neighbourhood association & 11 \\
\hline Construction of educational forest ecopaths and installation of a wind energy system & Neighbourhood association & 9 \\
\hline Implementation of ecospaces in kindergartens and environmental education & Neighbourhood association & 8 \\
\hline Planting native species to conserve water sources & Neighbourhood association & 11 \\
\hline Educational and processing station to produce compost and humus & Neighbourhood association & 11 \\
\hline Delivery of solar systems to heat water for the bathroom and kitchen & Neighbourhood association & 7 \\
\hline Delivery of solar systems to heat water for the bathroom and kitchen & Neighbourhood association & 6 \\
\hline Production of written and photographic material for environmental education workshops & Neighbourhood association & 8 \\
\hline Environmental education for solid waste management & Neighbourhood association & 6 \\
\hline Promotion of non-conventional renewable energies & $\begin{array}{l}\text { Various neighbourhood } \\
\text { associations }\end{array}$ & 9 \\
\hline Restoration of watersheds & $\begin{array}{l}\text { Various neighbourhood } \\
\text { associations }\end{array}$ & 10 \\
\hline Creation and equipment of educational spaces on plant nurseries and landscaping & Town & 9 \\
\hline Educational talks, recycling and composting & Town & 10 \\
\hline Training and recycling & Town & 7 \\
\hline Greenhouse installation, composting and recycling & Town & 10 \\
\hline $\begin{array}{l}\text { Transformation of a cultural and sports centre into an energy-efficient, water-efficient } \\
\text { sustainable centre with recycling and waste reduction and recycling }\end{array}$ & Town & 11 \\
\hline Dissemination and use of medicinal plants of the Mapuche people in the comuna & Town & 8 \\
\hline Establishment of an environmental round table for civil society in the Cajón del Maipo & Town & 11 \\
\hline Promotion and dissemination efforts to reduce and manage household solid waste & Town & 8 \\
\hline $\begin{array}{l}\text { Efforts to encourage and workshops on sustainable use of water resources } \\
\text { and wetland protection }\end{array}$ & Town & 9 \\
\hline Comprehensive treatment of solid household waste with biodigesters & Town & 9 \\
\hline Ecopark construction and recycling & Town & 6 \\
\hline Conservation of endangered species & Province & 9 \\
\hline Community radio stations on environmental issues & Province & 9 \\
\hline Meeting of youth leaders on environmental issues & Region & 7 \\
\hline Efforts to protect the river shrimp & Region & 9 \\
\hline Production and storage of medicinal species needed for traditional Mapuche medicine & Region & 9 \\
\hline Sharing of experiences of using and applying non-conventional renewable energies & Region & 8 \\
\hline Environmental study of flora & National reserve & 11 \\
\hline Creation of a biodiversity conservation centre & National reserve & 11 \\
\hline Youth environmental networks & Various comunas & 7 \\
\hline
\end{tabular}

Source: Prepared by the author, on the basis of data from the Ministry of the Environment of Chile. 